\title{
Standardowe i potencjalne markery nowotworowe u chorych na raka szyjki macicy
}

\author{
Beata Kotowicz, Małgorzata Fuksiewicz
}

Oznaczanie markerów nowotworowych od wielu lat znajduje zastosowanie w ginekologii onkologicznej. Znane dotychczas markery nowotworowe wykorzystywane są przede wszystkim w prognozowaniu i monitorowaniu przebiegu choroby.

Rutynowo oznaczanymi w surowicy krwi markerami nowotworowymi u chorych na płaskonabłonkowego raka szyjki macicy są: antygen SCCAg i CYFRA 21.1, a na raka gruczołowego - CA 125 i CEA. Stężenie SCCAg przed leczeniem pomocne jest w określeniu stopnia zaawansowania klinicznego i w prognozowaniu przebiegu choroby. Spadek stężenia SCCAg w surowicy krwi po zabiegu operacyjnym świadczy o jego radykalności. Uzyskane po zakończeniu leczenia wartości SCCAg u chorych na raka płaskonabłonkowego mają wysoką dodatnią wartość predykcyjną dla wykrycia wznowy lub odległych przerzutów. Komplementarne oznaczanie CYFRY 21.1 z SCCAg zwiększa czułość diagnostyczną, co ma istotne znaczenie $u$ chorych w niskich stopniach zaawansowania. W typie gruczołowym raka szyjki macicy markerem o najwyższej czułości jest CA 125. Stężenie jego narasta wraz ze stopniem zaawansowania klinicznego, korelując ze stanem węzłów chłonnych miednicy mniejszej i okołoaortalnych. Ponadto stężenie CA 125 w surowicy krwi jest niezależnym czynnikiem prognostycznym dla czasu wolnego od choroby. Czułość diagnostyczna CA 125 w raku gruczołowym jest wyższa, w porównaniu z CEA, który jest uznanym markerem dla tego typu nowotworu. W ostatnich latach okazało się, że cytokiny mogą być klinicznie użytecznymi potencjalnymi markerami. U chorych na raka szyjki macicy istotne znaczenie może mieć oznaczanie stężeń, między innymi: naczyniowo-śródbłonkowego czynnika wzrostu (VEGF) oraz jego rozpuszczalnych receptorów: VEGFR1 (sFLT1) i VEGFR2, interleukiny 6 (IL-6) i rozpuszczalnych receptorów czynnika martwicy nowotworów: sTNF RI, sTNF RII. U chorych na raka szyjki macicy stężenie VEGF narasta wraz ze stopniem zaawansowania klinicznego i wielkością guza i może być klinicznie użyteczne w monitorowaniu przebiegu choroby, a także w ocenie czasu wolnego od choroby i czasu całkowitego przeżycia. Stężenia receptorów VEGFR1 i VEGFR2 mogą mieć znaczenie prognostyczne. Na podstawie przeglądu piśmiennictwa ostatnich lat wynika, że oznaczanie np. YKL-40, gammaglutamylotransferazy (GGT), leptyny, metaloproteinazy 9 (MMP-9) czy też receptora HER2 u chorych na raka szyjki macicy może mieć również zastosowanie kliniczne, co stwarza szansę poprawy diagnostyki, a przez to skuteczności leczenia chorych na raka szyjki macicy.

\section{Standard and potential tumor markers in patients with cervical cancer}

The determination of tumor markers in gynecological oncology has been useful for many years. Previously known tumor markers are used mainly when predicting and monitoring the disease.

The routinely determined tumor markers in the serum of patients with squamous cell carcinoma of the cervix are: antigen SCCAg and CYFRA 21.1, and for patients with adenocarcinoma CA 125 and CEA. The concentration of SCCAg before treatment is useful for the determination of the clinical stage, as well as for the prediction of the disease. The decrease in the concentration of SCCAg in serum after surgery proves radical activity. Values of SCCAg in patients with squamous cell carcinoma after treatment, have a greater positive predictive value for the detection of a recurrence or of distant metastase. The complementary determination of CYFRA 21.1 with SCCAg increases diagnostic sensitivity, which is essential for patients in low stages of the disease. In adenocarcinoma, the tumor marker of the greatest sen- 
sitivity is CA 125. Its concentrations increase along with clinical stage, correlating with pelvic and para-aortic lymph node status. Moreover, the concentrations of CA 125 in serum are independent predictors for disease-free survival. The diagnostic sensitivity of CA 125 in adenocarcinoma is greater in comparison to CEA.

During the past several years it has appeared that potentially, cytokines can be clinically useful markers. In patients with cervical cancer of significant interest is the determination of the concentrations between vascular endothelial growth factor (VEGF) and its soluble receptors:VEGFR1 (sFLT1) and VEGFR2, interleukin 6 (IL-6) and soluble receptors of the tumor necrosis factors: STNF RI, sTNF RII. In patients with cervical cancer, the concentrations of VEGF increase with the clinical stage and the tumor size. They may be clinically useful when monitoring the disease, as well as evaluating both the disease-free survival and overall survival. The concentrations of receptors VEGFR1 and VEGFR2 may play the role of a prognostic factor. On the basis of the literature review collected over the past several years, it appears that the determination of e.g., YKL-40, gamma glutamyltransferase (GGT), leptin, matrix metalloproteinase 9 (MMP-9) or HER2 receptor in patients with cervical cancer may also have a clinical application to create an opportunity to improve diagnosis and thus the effectiveness in treatment of patients with cervical cancer.

NOWOTWORY Journal of Oncology 2013; 63, 5: 403-407

Słowa kluczowe: markery nowotworowe, rak szyjki macicy, VEGF, IL-6, TNF, YKL-40

Key words: tumor markers, cervical cancer, VEGF, IL-6, TNF, YKL-40

\section{Wprowadzenie}

Markery nowotworowe od szeregu lat mają istotną wartość kliniczną w ginekologii onkologicznej. Rak szyjki macicy jest częstym nowotworem złośliwym narządu rodnego kobiety. Zachorowalność w 2010 roku na nowotwory złośliwe szyjki macicy wynosiła 10,3/10 klasyfikując się po nowotworach złośliwych trzonu macicy i jajnika. [1]. Wykrycie raka w stadium przedinwazyjnym stwarza możliwość całkowitego wyleczenia chorych. U chorych na raka szyjki macicy markery nowotworowe są powszechnie stosowane w diagnostyce, monitorowaniu leczenia, jak również w ocenie przebiegu choroby. Rutynowo oznaczanym w surowicy krwi markerem nowotworowym u chorych na płaskonabłonkowego raka szyjki macicy jest antygen SCCAg bądź CYFRA 21.1, a u chorych na raka gruczołowego - CA 125 lub CEA.

W piśmiennictwie ostatnich lat dotyczącym raka szyjki macicy coraz częściej spotyka się doniesienia na temat przydatności oznaczeń stężeń zarówno znanych, jak i nowych markerów nowotworowych, w tym niektórych cytokin oraz innych parametrów biochemicznych.

\section{Standardowe markery nowotworowe w raku szyjki macicy \\ Antygen raka płaskonabłonkowego - SCCAg}

Standardowym markerem nowotworowym płaskonabłonkowego raka szyjki macicy jest SCCAg; glikoproteina, podfrakcja antygenu TA-4, wyodrębniona w 1977 roku przez Kato i Torrigoe z komórek raka płaskonabłonkowego szyjki macicy [2]. Obecność SCCAg wykazano w prawidłowych komórkach nabłonkowych pochwy, szyjki macicy, płuc, przełyku i skóry, jak i w zmienionych nowotworowo. Nieznacznie podwyższone stężenia SCCAg mogą występować u chorych z zaburzeniami funkcji nerek, wątroby, w chorobach płuc, niezłośliwych guzach głowy i szyi oraz w niektórych chorobach skóry (łuszczyca, egzema, pęcherzyca). W takich przypadkach oznaczanie SCCAg ma znacznie ograniczoną wartość $[3,4]$. Podwyższone stężenia SCCAg spotyka się u znacznego odsetka chorych na płaskonabłonkowego raka szyjki macicy, płuca oraz w nowotworach głowy i szyi [5, 6]. Czułość diagnostyczna SCCAg, w zależności od typu histopatologicznego i stopnia zaawansowania klinicznego, u chorych na raka płaskonabłonkowego mieści się w granicach od ok. $30 \%$ do $80 \%$, natomiast u chorych na raka gruczołowego jest znacznie niższa i wynosi od 10\% do 38\%. Oznaczanie SCCAg u chorych na płaskonabłonkowego raka szyjki macicy ma istotne znaczenie na każdym etapie procesu diagnostycznego. Wyjściowe stężenie SCCAg oznaczone przed leczeniem ma wartość prognostyczną, jest pomocne w określeniu stopnia zaawansowania klinicznego, korelując ze stanem węzłów chłonnych, wielkością guza i głębokością nacieku [7-12]. Oznaczanie SCCAg po zabiegu operacyjnym ma znaczenie w ocenie radykalności zabiegu. Śledzenie dynamiki zmian stężeń SCCAg u chorych leczonych radio- lub chemioterapią jest przydatne w ocenie skuteczności stosowanej terapii. Uzyskane po zakończeniu leczenia wartości SCCAg u chorych na raka płaskonabłonkowego mają wysoką dodatnią wartość predykcyjną dla wykrycia wznowy lub odległych przerzutów [11-15].

\section{Antygen nowotworowy CA 125}

Istotną cechą kliniczno-patologiczną u chorych na raka szyjki macicy, budzącą duże zainteresowanie, jest typ utkania histopatologicznego nowotworu, ponieważ gruczołowa postać raka cechuje się większą agresywnością oraz częstością występowania przerzutów do węzłów chłonnych, co może mieć wpływ na gorsze wyniki leczenia i wcześniejsze 
wystąpienie nawrotów choroby [16]. U chorych na raka gruczołowego szyjki macicy markerem o wyższej czułości niż SCCAg okazał się CA $125[9,17,18]$.

Antygen CA 125, wykrywany przy pomocy monoklonalnego przeciwciała OC-125, jest mucynopodobną glikoproteiną. Jego ekspresję wykazano w nabłonku prawidłowym, między innymi, opłucnej osierdzia i otrzewnej oraz w nowotworach złośliwych pochodzenia nabłonkowego. Nieznacznie podwyższone stężenia CA 125 obserwuje się w pierwszym trymestrze ciąży oraz w różnych stanach patologicznych, np. chorobach autoimmunologicznych, w stanach zapalnych wątroby, trzustki, przydatków, w marskości wątroby. W znacznych ilościach syntetyzowany jest przez komórki nowotworowe jajnika, niewytwarzające śluzu. CA 125 może być także produkowany przez komórki raka szyjki macicy $[9,19,20]$. Czułość diagnostyczna tego antygenu, korelując ze stopniem zaawansowania klinicznego, jest wyższa u chorych na raka gruczołowego (42\%) niż u chorych na raka płaskonabłonkowego $(23 \%)[8,17,18]$. Ponadto autorzy opisują jego przydatność w ocenie stanu węzłów chłonnych miednicy mniejszej i węzłów okołoaortalnych $[8,9,17,18,21]$. W badaniach własnych wykazano, że odsetki chorych z podwyższonymi stężeniami CA 125 były ponad dwukrotnie wyższe u chorych z obecnością przerzutów do węzłów chłonnych miednicy mniejszej i okołoaortalnych niż u chorych bez przerzutów [8]. Ponadto stwierdzono wyższą czułość diagnostyczną CA 125 w raku gruczołowym w porównaniu z CEA, który jest uznanym markerem dla tego typu nowotworu [22]. Stężenia CA 125 w surowicy krwi są niezależnym czynnikiem prognostycznym dla czasu wolnego od choroby $[9,17,18]$.

\section{Antygen karcinoembrionalny (CEA)}

Antygen CEA został wyizolowany z tkanki jelita grubego i opisany jako pierwszy marker nowotworowy w roku 1965 przez Golda i Freedmana. Fizjologicznie stężenia CEA w surowicy krwi osób dorosłych są śladowe, ponieważ tylko w niewielkich ilościach wytwarzany jest on przez dojrzałe komórki jelit, trzustki i wątroby. Miernie podwyższone stężenia CEA obserwuje się u osób palących, u kobiet w ciąży oraz w stanach zapalnych wątroby, jelit i płuc. Natomiast znacznie podwyższone jego wartości występują przede wszystkim u chorych na raka jelita grubego i odbytnicy, stąd CEA uznany został jako standardowy marker w tych lokalizacjach nowotworu [23]. CEA może być także wytwarzany i uwalniany do krążenia u chorych na nowotwory o innych umiejscowieniach, między innymi w nowotworach narządu rodnego, żołądka, trzustki, piersi, płuca, pęcherza moczowego, gruczołu krokowego oraz w przerzutach do wątroby [6, 23-25]. W piśmiennictwie opisywany jest związek stężeń CEA z typem histopatologicznym raka, w rakach gruczołowych szyjki macicy podwyższone stężenia CEA obserwuje się częściej niż w płaskonabłonkowych [10, 16, 26].

\section{Rozpuszczalny fragment cytokeratyny 19 (CYFRA 21.1)}

CYFRA 21.1 jest rozpuszczalnym w osoczu fragmentem cytokeratyny 19. Cytokeratyny są nierozpuszczalnymi białkami strukturalnymi komórek nabłonkowych oraz komórek pochodzenia nabłonkowego. Cytokeratyna 19 występuje w cytozolu nabłonka. Komórka, ulęgając apoptozie, wydziela do krwioobiegu rozpuszczalne fragmenty cytokreatyn, z których jeden zdefiniowany jest za pomocą dwóch przeciwciał monoklonalnych: BM-19.21 i KS-19.1, stąd nazwa testu — CYFRA 21.1. Podwyższone stężenia tego markera stwierdzono u znacznego odsetka chorych na niedrobnokomórkowego raka płuca oraz w wielu innych nowotworach płaskonabłonkowych o innym umiejscowieniu [5, 10, 23, 27].

$\mathrm{U}$ chorych na raka szyjki macicy obserwuje się wzrost stężeń CYFRY 21.1 z częstością zależną od stopnia klinicznego zaawansowania nowotworu. Niektórzy autorzy opisują, że oznaczanie CYFRY 21.1 przed leczeniem może mieć wartość prognostyczną. W piśmiennictwie podkreślana jest niższa użyteczność diagnostyczna tego markera w raku szyki macicy - w porównaniu z wartością oznaczeń SCC. Jednak komplementarne oznaczanie stężeń CYFRY 21.1 z SCC zwiększa czułość diagnostyczną badania [8, 27, 28].

\section{Cytokiny jako potencjalne markery}

Cytokiny odgrywają istotną rolę w patogenezie i progresji nowotworów złośliwych. W procesach nowotworowych dochodzi do niekontrolowanej nadekspresji genów cytokin i receptorów cytokinowych, co prowadzi do ich zwiększonej syntezy w komórkach, w których rozwija się nowotwór. Oznaczanie stężeń wybranych cytokin w surowicy krwi chorych może być przydatne w diagnostyce i monitorowaniu leczenia chorych na nowotwory złośliwe. W badaniach własnych, jak również w pracach innych autorów wykazano związek pomiędzy stężeniami cytokin a cechami kliniczno-patologicznymi chorych na nowotwory złośliwe o różnej lokalizacji oraz ich znaczenie jako niezależnych czynników prognostycznych [29-33].

Na podstawie przeglądu piśmiennictwa ostatnich lat wynika, że u chorych na raka szyjki macicy — spośród szerokiego panelu cytokin - kliniczne znaczenie może mieć oznaczanie stężeń, miedzy innymi naczyniowo-śródbłonkowego czynnika wzrostu (VEGF) oraz jego rozpuszczalnych receptorów: VEGFR1 (sFLT1) i VEGFR2, interleukiny 6 (IL-6) i rozpuszczalnych receptorów czynnika martwicy nowotworów: sTNF RI, sTNF RII.

Spośród cytokin proangiogennych istotne jest oznaczanie stężeń czynnika wzrostu VEGF, który odgrywa szczególną rolę $w$ procesach neoangiogenezy, a zatem w progresji choroby oraz w powstawaniu przerzutów [34]. U chorych na raka szyjki macicy stężenia VEGF narastają wraz ze stopniem zaawansowania klinicznego i wielkością guza. W konsekwencji skutecznego leczenia następuje spadek stężeń VEGF 
w surowicy krwi chorych, co może być pomocne w monitorowaniu przebiegu choroby. Oznaczanie stężeń VEGF przed leczeniem u chorych na raka szyjki macicy może być klinicznie użyteczne w ocenie czasu wolnego od choroby i czasu całkowitego przeżycia [9, 35-38].

Czynnik wzrostu VEGF jest ligandem dla dwóch receptorów: VEGFR1 i VEGFR2, natomiast jego izoformy: VEGF-C i VEGF-D są ligandami dla receptora VEGFR3. W prawidłowych warunkach ekspresja tych receptorów ma miejsce w komórkach śródbłonkowych, a ich nadekspresję zaobserwowano w wielu typach nowotworów, co może świadczyć o udziale w patologicznej angiogenezie [34, 39]. Poziom ekspresji VEGFR2 może być związany z odpowiedzią na leczenie raka szyjki macicy [40], natomiast stężenia izoform śródbłonkowego czynnika wzrostu oraz jego receptorów oznaczane w surowicy krwi chorych na raka szyjki macicy mogą odgrywać rolę potencjalnych biomarkerów oraz czynników prognostycznych [41-43].

W wyniku zaburzeń układu immunologicznego w odpowiedzi na wzrost nowotworu dochodzi do zwiększonej syntezy wielu cytokin, miedzy innymi IL-6 i TNF. Cytokina prozapalna IL-6 odgrywa rolę w patogenezie i rozwoju nowotworów, między innymi poprzez hamowanie apoptozy oraz indukcję angiogenezy w obrębie guza [44]. Oznaczanie stężeń IL-6 przed leczeniem u chorych na raka szyjki macicy, może mieć znaczenie w ocenie czasu wolnego od choroby i czasu całkowitego przeżycia [45, 46]. Stężenia IL-6 korelują ze stopniem zaawansowania klinicznego niezależnie od typu histopatologicznego nowotworu oraz ze stopniem złośliwości histologicznej u chorych na gruczołowego raka szyjki macicy $[8,18]$. Ponadto łączne oznaczanie IL-6 ze standardowym markerem nowotworowym SCCAg, szczególnie u chorych we wczesnych stopniach zaawansowania klinicznego, zwiększa jego czułość diagnostyczną o około 30\% [22, 45].

Czynnik martwicy nowotworów TNF wraz z IL-6 i lL-1 odgrywa istotną rolę w zapoczątkowaniu reakcji ostrej fazy. Jest ważnym mediatorem wpływającym na aktywność monocytów, makrofagów, neutrofilów, limfocytów T i B, komórek NK, eozynofilów oraz hepatocytów. Aktywność czynnika martwicy nowotworu neutralizują wolne formy jego receptorów, które w dużych stężeniach działają jako inhibitory, co może sprzyjać progresji procesu nowotworowego [47]. STNF RI i sTNF RIl jako rozpuszczalne formy receptorów TNF powstają w wyniku proteolitycznego rozszczepiania receptorów błonowych pod wpływem różnych czynników endo- i egzogennych. Obie formy rozpuszczalnych receptorów wykazują zdolność wiązania krążącego TNF- $\alpha$. Wykazano, że receptory te mogą mieć znaczenie prognostyczne u chorych na nowotwory złośliwe o różnym umiejscowieniu [48]. U chorych na gruczołowego raka szyjki macicy stężenie sTNF RI wykazywało wyższą czułość diagnostyczną niż CA 125, a oznaczanie obu tych receptorów może być pomocne w ocenie czasu wolnego od choroby [18].

\section{Inne biomarkery}

Biomarker YKL-40, zidentyfikowany na początku lat 90, w ostatnim czasie znajduje zastosowanie w diagnostyce onkologicznej. Jest glikoproteiną, czynnikiem antyapoptycznym i czynnikiem wzrostu dla niektórych komórek. Bierze udział w procesach proliferacji oraz angiogenezy. Może mieć wartość niezależnego czynnika prognostycznego, między innymi u chorych na raka piersi, jelita grubego, płuca i raka jajnika [49]. U chorych na raka szyjki macicy typu płaskonabłonkowego wykazano wysoką czułość diagnostyczną dla YKL-40, podobnie jak dla SCCAg. Natomiast w raku gruczołowym już w niskich stopniach zaawansowania jego czułość jest wyższa niż CA 125 i SCCAg. Ponadto podwyższone stężenie YKL-40 przed leczeniem może być złym czynnikiem prognostycznym, niezależnie od stopnia zaawansowania klinicznego i wieku chorych na raka szyjki macicy [50].

W najnowszym piśmiennictwie spotyka się pojedyncze prace na temat klinicznego zastosowania innych biomarkerów u chorych na raka szyjki macicy. Wykazano między innymi, że oznaczanie gammaglutamylotransferazy (GGT), leptyny, metaloproteinazy 9 (MMP-9) czy też receptora HER2 może mieć znaczenie w prognozowaniu przebiegu choroby [36, 51, 52]. Inni badacze sugerują, że np. ocena aktywności enzymu odwrotnej transkryptazy ludzkiej telomerazy (hTERT) u chorych przed leczeniem może być pomocna w diagnostyce raka szyjki macicy ze względu na jego wysoką czułość i korelację ze stopniem zaawansowania [53].

\section{Podsumowanie}

Rozwój immunodiagnostyki onkologicznej — jak do tej pory — nie wpłynął w istotny sposób na wcześniejsze wykrywanie raka szyjki macicy, dotychczas kluczową rolę w tym rozpoznaniu odgrywają badania cytologiczne. Standardowo oznaczane markery nowotworowe u chorych na raka szyjki macicy, ze względu na niezadowalającą czułość w niskich stopniach zaawansowania nowotworu, mają zastosowanie przede wszystkim w prognozowaniu i monitorowaniu przebiegu choroby. Najnowsze doniesienia na temat klinicznego zastosowania nowych biomarkerów budzą nadzieje na poprawę szeroko pojętej diagnostyki, co może być pomocne w optymalizacji metod leczenia.

\section{Dr n. med. Beata Kotowicz}

Zakład Markerów Nowotworowych

Centrum Onkologii — Instytut im. Marii Skłodowskiej-Curie ul. Roentgena 5, 02-781 Warszawa

e-mail:bkotowicz@coi.pl

Otrzymano: 2 lutego $2013 \mathrm{r}$.

Przyjęto do druku: 12 marca 2013 r.

\section{Piśmiennictwo}

1. Wojciechowska U, Didkowska J, ZatońskiW. Nowotwory złośliwew Polsce w 2010 roku. Warszawa: Krajowy Rejestr Nowotworów, 2012. 
2. Kato H, Nagaya T, Torigoe T. Heterogeneity of tumor antigen TA-4 of squamous cell carcinoma in relation to its appearance in the circulation. Gann 1984; 75: 433-435.

3. Molina R, Filella X, Torres MD i wsp. SCC antigen measured in malignant and nonmalignant diseases. Clin.Chem 1990; 36: 251-254.

4. El-Rachkidy RG, Young HS, Griffiths CE i wsp. Humoral autoimmune responses to the squamous cell carcinoma antigen protein family in psoriasis. J Invest Dermatol 2008; 128: 2219-2224.

5. Banal A, Hacene K, Berthelot-Ruff E i wsp. Comparison of CYFRA 21and SCC assays in head and neck tumors. Tumor Biol 2001:22:1-3.

6. Molina R, Fillela X, Auge JM i wsp. Tumor markers (CEA, CA 125 , CYFRA 21-1, SCC and NSE) in patients with non-small cell lung cancer as an aid in histological diagnosis and prognosis. Comparison with the main clinical and pathological prognostic factor. Tumor Biol 2003; 24: 209-218.

7. Massuger LF, Koper NP, Thomas CM i wsp. Improvement of clinical staging in cervical cancer with serum squamous cell carcinoma antigen and CA 125 determinations. Gynecol Oncol 1997; 64: 473-476.

8. Kotowicz B, Fuksiewicz M, Kowalska M i wsp. The value of tumor marker and cytokine analysis for the assessment of regional lymph node status in cervical cancer patients. Int J Gynecol Cancer 2008; 18:1279-1284.

9. Gadducci A, Tana R, Cosio Si wsp. The serum assay of tumour markers in the prognostic evaluation, treatment monitoring and follow up patients with cervical cancer; review of the literature. Crit Rev Oncol Hematol 2008; 66: 10-20.

10. Ueda Y, EnomotoT, Kimura T i wsp. Serum Biomarkers for Early Detection of Gynecologic Cancers. Cancer 2010; 2, 1312-1327.

11. van de Lande J, Davelaar EM, von Mendorff-Pouilly S i wsp. SCC-Ag, lymph node metastases and sentinel node procedure in early stage squamous cell cervical cancer. Gynecol.Oncol 2009; 112: 119-125.

12. Lee $Y Y$, Choi $\mathrm{CH}$, Sung $\mathrm{CO}$ i wsp. Prognostic value of pre-treatment circulating monocyte count in patients with cervical cancer: comparison with SCC-Ag level. Gynecol Oncol 2012; 124: 92-97.

13. Olsen JR, Dehdashit F, Siegel BA i wsp. Prognostic utility of squamous cell carcinoma antigen in carcinoma of the cervix: association with pre- and post treatment FDG-PET. Int J Radiat Oncol Biol Phys 2011; 81: 772-777.

14. Hirakawa $M$, Nagai $Y$, Inamine $M I$ wsp. Predictive factor of distant recurrence in locally advanced squamous cell carcinoma of the cervix treated with concurrent chemioradiotherapy. Gynecol.Oncol 2008; 108: 126-129.

15. Pan L, Cheng J, Zhou M i wsp. The SUVmax (maximum standardized uptake value for F-18 fluorodeoxyglucose) and serum squamous cell carcinoma antigen (SCC-ag) function as prognostic biomarkers in patients with primary cervical cancer. J Cancer Res Clin Oncol 2012; 138: 239-246.

16. Berrington de Gonzalez A, Green J. Comparison of risk factors for invasive squamous cell carcinoma and adenocarcinoma of the cervix: Collaborative reanalysis of individual data on 8097 women with squamous cell carcinoma and 1374 women with adenocarcinoma from 12 epidemiological studies. Int J Cancer 2007; 120: 885-891.

17. Bender DP, Sorosky J, Buller RE i wsp. Serum CA 125 is an independent prognostic factor in cervical adenocarcinoma. Am J Obstet Gynecol 2003; 189: 113-117.

18. Kotowicz B, Kaminska J Fuksiewicz M i wsp. Clinical significance of serum CA 125 and sTNF́ RI in cervical adenocarcinoma patients. Int J Gynecol Cancer 2010; 20: 588-592.

19. Duffy MJ, Bonfrer JM, Kulpa J i wsp. CA 125 in ovarian cancer: European Group on Tumor Markers guidelines for clinical use. Int J Gynecol Cancer 2005; 15: 679-691.

20. Schoniger-Hekele M, Muller C. The combined elevation of tumor markers CA 19.9 and CA 125 in liver disease patients is highly specific for severe liver fibrosis. Dig Dis Sci 2006; 51: 338-345.

21. Tsai CC, Liu YS, Huang EY i wsp. Value of preoperative serum CA 125 in early-stage adenocarcinoma of the uterine cervix without pelvic lymph node metastasis. Gynecol Oncol 2006; 100: 591-595.

22. Kotowicz B, Kowalska M, Fuksiewicz M i wsp. Kliniczne znaczenie komplementarnych oznaczeń standardowych markerów nowotworowych i wybranych cytokin w surowicy krwi chorych na raka szyjki macicy. Wspolcz Onkol 2006; 10: 292-296.

23. Voorzanger-Rousselot N, Garnero P. Biochemical markers in oncology. Part I: Molecular basis. Part II: Clinical uses. Cancer Treat Rev 2007; 33: 230-283.

24. Duffy MJ: Evidence for the clinical use tumor markers. Ann Clin Biochem 2004; 41: 370-377.

25. Huang EY, Hsu HC, Sun LM i wsp. Prognostic value of pretreatment carcinoembryonic antigen after definitive radiotherapy with or without concurrent chemotherapy for squamous cell carcinoma of the uterine cervix. Int J Radiat Oncol Biol Phys 2011; 81: 1105-1113.

26. Tabata T, Takeshima N, Tanaka N i wsp. Clinical value of tumor markers for early detection of recurrence in patients with cervical adenocarcinoma and adenosquamous carcinoma. Tumor Biol 2000; 21: $375-380$.
27. Molina R, Filella X, Auge JM i wsp. CYFRA 21.1 in patients with cervical cancer: comparison with SCC and CEA. Anticancer Res 2005; 25: 1765-1771.

28. Davelaar EM, van de Lande J, von Mensdorff-Pouilly S i wsp. A combination of serum tumor markers identifies high-risk patients with early-stage squamous cervical cancer. Tumor Biol 2008; 29: 9-17.

29. Rutkowski P, Kamińska J, Kowalska M i wsp. Cytokine and cytokine receptor serum levels in adult bone sarcoma patients: correlations with local tumor extent and prognosis. J Surg Oncol 2003; 84: 151-159.

30. Kamińska J, Kowalska M, Kotowicz B i wsp. Pretreatment serum levels of cytokines and cytokine receptors in patients with non-small cell lung cancer and correlations with clinicopathological features and prognosis. M-CSF - an independent prognostic factor. Oncology 2006; 70: 115-125.

31. Fuksiewicz M, Kowalska M, Kotowicz B i wsp. Serum soluble tumour necrosis factor receptor type I levels independently predict prognosis in breast cancer patients. Clin Chem Lab Med 2010; 48: 1481-1486.

32. Kowalska M, Tajer J, Chechlinska M i wsp. Serum macrophage colony-stimulating factor (M-CSF) in patients with Hodgkin lymphoma. Med Oncol 2012; 29: 2143-2147.

33. Peng RQ, Ding $Y$, Zhang $X$ i wsp. A pilot study of paclitaxel combined with hemcitabine followed by interleukin- 2 and granulocyte macrophage colony-stimulating factor for patients with metastatic melanoma. Cancer Biol Ther 2012; 13: 1443-1448.

34. Kerbel RS. Tumor Angiogenesis. N Engl J Med 2008; 358: 2039-2049.

35. Srivastava S, Gupta A, Agarwal GG i wsp. Correlation of serum vascular endothelial growth factor with clinopathological parameters in cervical cancer. Biosci Trends 2009; 3: 144-150.

36. Lebrecht A, Ludwig E, Huber A i wsp. Serum vascular endothelial growth factor and serum leptin in patients with cervical cancer. Gynecol Oncol 2002; 85: 32-35.

37. Zusterzeel PLM, Span PN, Dijksterhuis MGK i wsp. Serum vascular endothelial growth factor: a prognostic factor in cervical cancer. J Cancer Res Clin Oncol 2009; 135: 283-290.

38. Katanyoo K, Chantaraseri A, Chongtanakon M i wsp. Pretreatment levels of serum vascular endothelial growth factor do not correlate with outcome in patients with locally advanced cervical cancer. Asian Pac J Cancer Prev 2011: 12: 699-702.

39. Shibuya M. Vascular endothelial growth factor and its receptor system: physiological functions in angiogenesis and pathological roles in various diseases. J Biochem 2013; 153: 13-19.

40. Nagy VM, Buiga R, Bie I i wsp. Expression of VEGF, VEGFR, EGFR, COX-2 and MVD in cervical carcinoma, in relation with the response to radio-chemotherapy. Rom J Morphol Embryol 2011; 52: 53-59.

41. Mitsuhashi A, Suzuka K, Yamazawa Ki wsp. Serum vascular endothelial growth factor (VEGF) and VEGF-C levels as tumor markers in patients with cervical carcinoma. Cancer 2005; 103: 724-730.

42. Landt $\mathrm{S}$, Wehling $\mathrm{M}$, Heidecke $\mathrm{H}$ i wsp. Prognostic significance of angiogenic factors in uterine cervical cancer. Anticancer Res 2011; 31: 2589-2595.

43. Kuemmel S, Thomas A, Landt S i wsp. Circulating Vascular Endothelia Growth Factors and their Soluble Receptors in Pre-invasive, Invasive and Recurrent Cervical Cancer. Anticancer Res 2009; 29: 641-646.

44. Wei LH, Kuo ML, Chen CA i wsp. Interleucin- 6 promotes cervical tumor growth by VEGF - dependent angiogenesis via a STAT3 pathway. Oncogene 2003; 22: 1517-1527.

45. Scambia G, Testa U, Panici BP i wsp. Interleucin- 6 serum levels in patients with gynecological tumors. Int J Cancer 1994; 57: 318-323.

46. Chopra V, Dinh TV, Hannigan EV. Circulating serum levels of cytokines and angiogenic factors in patients with cervical cancer. Cancer 1998; 16: $152-159$.

47. Gupta S. Tumor necrosis factor-alpha-induced apoptosis in T cells from aged humans: a role of TNFR-I and downstream signalling molecules. Exp Gerontol 2002; 37: 293-299.

48. Gregorc V, Spreafico A, Floriani I i wsp. Prognostic value of circulating chromogranin $\mathrm{A}$ and soluble tumor necrosis factor receptors in advanced nonsmall cell lung cancer. Cancer 2007; 110: 845-853.

49. Johansen JS, Jensen BV, Roslind A, Nielsen D, Price PA. Serum YKL-40, a new prognostic biomarker in cancer patients? Cancer Epidemiol Biomarks Prev 2006; 15: 194-202.

50. Mitsuhashi A, Matsui H, Usui $\mathrm{H}$ i wsp. Serum YKL-40 as a marker for cervical adenocarcinoma. Ann Oncol 2009; 20: 71-77.

51. Polterauer S, Hofstetter G, Grimm C i wsp. Relevance of gamma-glutamyltransferase - a marker for apoptotic balance - in predicting tumor stage and prognosis in cervical cancer. Gynecol Oncol 2011; 122: 590-594.

52. Kopczyńska E, Markiewicz R, Biedka M i wsp. Wpływ progresji nowotworowej na stężenie zewnątrzkomórkowej domeny receptora HER2 i metaloproteinazy 9 w surowicy chorych na raka szyjki macicy. Wspolcz Onkol 2008; 6: 261-266.

53. Porika M, Tippani R, Mohammad A i wsp. Evaluation of serum human telomerase reverse transcriptase as a novel marker for cervical cancer. Int J Biol Markers 2011; 26: 22-26. 